\title{
PERUBAHAN SOSIAL BUDAYA DESA PURWODADI KECAMATAN BARAT KABUPATEN MAGETAN TAHUN 1990-2010
}

\author{
Debi Setiawati \\ Warih Yudo Sanjoyo *)
}

\begin{abstract}
Abstrak
Penelitian ini bertujuan untuk mengungkap perkembangan sosial budaya Desa Purwodadi Kecamatan Barat Kabupaten Magetan tahun 19902010. Jenis penelitian deskriptif kualitatif. Data dikumpulkan dengan teknik observasi, wawancara mendalam, mencatat dokumen dan arsip. Validitas data diperoleh melaui trianggulasi sumber, dan teknik. Analisis data yang digunakan adalah analisis interaktif.

Hasil penelitian menunjukkan bahwa sebelum tahun 1990-an hampir seluruh masyarakat Desa Purwodadi menggantungkan kehidupannya pada sektor pertanian. Perubahan sosial diawali dengan semakin menyempitnya lahan pertanian serta sektor pertanian tidak lagi menjanjikan kemapanan status sosial. Yang dilakukan masyarakat Purwodadi adalah menyewakan lahan kepada penyewa perorangan maupun PG Purwodadie. Struktur sosial perlahan mulai berubah. Nilai-nilai sosial gotong royong mulai luntur. Satusatunya yang masih tersisa adalah tradisi Bersih Desa. Desa Purwodadi sebagai bekas pusat Pemerintahan Kadipaten Purwodadi yang berlatar belakang agama Islam membawa dampak pada tumbuh dan berkembangnya kesenian-kesenian yang bernafaskan Islam, antara lain terbang, gembrung, dan jedor. Kesenian-kesenian tersebut pernah ada di Desa Purwodadi sebelum tahun 1990-an, saat ini mulai tergeser oleh bentuk-bentuk kesenian modern yang lebih mementingkan aspek hiburan.
\end{abstract}

\section{Kata Kunci: Desa, Sosial Budaya}

" Debi Setiawati, Dosen Pendidikan Sejarah IKIP PGRI MADIUN

Warih Yudo Sanjoyo, Mahasiswa Pendidikan Sejarah IKIP PGRI MADIUN

66|Agastya Vol. 02 No. 01 Januari 2012 


\section{Pendahuluan}

Kurang lebih $80 \%$ dari wilayah Indonesia merupakan wilayah pedesaan. Peran pokok desa terletak dibidang ekonomi, yaitu sebagai tempat memproduksi bahan-bahan pangan yang tidak hanya di gunakan untuk memenuhi kebutuhan lokal, tetapi juga memenuhi kebutuhan nasional bahkan internasional. Optimalisasi peran pedesaan tidak dapat dilepaskan dari unsurunsur desa itu sendiri, antara lain:daerah dalam artian tanah-tanah yang produktif, lokasi, luas dan batas geografi setempat; penduduk, yang meliputi jumlah, pertambahan, kepadatan, persebaran dan mata pencaharian penduduk desa setempat. Tata Kehidupan, dalam hal ini pola tata pergaulan dan ikatan-ikatan pergaulan warga desa yang menyangkut seluk-beluk kehidupan masyarakat desa atau rural society (Bintarto, 1984:14).

Unsur tersebut saling mengikat satu dengan yang lain dan tidak dapat dipisahkan atau berdiri sendiri-sendiri. Unsur-unsur itu mampu memberikan karakteristik dari masing-masing desa sehingga memunculkan corak yang khas. Daerah menyediakan kemungkinan dan sumber daya alam, penduduk menggunakan kemungkinan yang disediakan oleh daerah guna mempertahankan hidup. Tata kehidupan yang baik memberikan jaminan akan ketentraman dan keserasian hidup bersama di desa (Bintarto, 1984:14).

Manusia dan daerah atau kondisi geografis adalah dua hal yang tidak dapat dipisahkan dalam pembentukan suatu masyarakat. Daldjoeni (1982:27) menyebutkan manusia dalam menciptakan segala sesuatu di sepanjang sejarahnya selalu dipengaruhi oleh alam lingkungannya. Kondisi alam yang kurang menguntungkan seperti kekeringan, suhu panas atau kelembaban yang sangat tinggi akan menimbulkan perubahan pada karakter tanaman ataupun hewan secara temporer atau permanen. Pada kehidupan manusia tentu ini menjadi masalah karena menyebabkan kurangnya persediaan bahan makanan dan akhirnya mempengaruhi besar kecilnya otat serta penciptaan kebiasaan baru yang didasari pada kekhasan karakteristik daerah atau kondisi geografis setempat Daldjoeni, 1982:27).

Secara sosiologis, dalam sistem kemasyarakatan terjadi hubungan antarpribadi, antarkelompok maupun pribadi dengan kelompok. Hubungan yang demikian disebut interaksi sosial, yang menyangkut proses saling mempengaruhi antar pihak dalam berinteraksi. Dalam interaksi yang berulang-ulang akan timbul kelompok sosial. Kelompok sosial merupakan himpunan atau kesatuan orang-orang yang memiliki kepentingan bersama yang sangat erat, sehingga masing-masing anggota merasa menjadi bagian dari kelompok sebagai satu kesatuan yang utuh. Kehidupan masyarakat di dalam kelompok-kelompok sosial tersebut cenderung menghasilkan kebudayaan. Kebudayaan tersebut merupakan perwujudan karya, cipta, rasa, dan karsa manusia. Perwujudan karya dan penciptaan bersumber dari akal budi manusia, rasa bersumber dari perasaan manusia, dan karsa bersumber dari kehendak manusia. Oleh karena itu unsur akal, budi, perasaan, dan kehendak manusia yang menggerakkan seseorang menciptakan aktifitas tertentu yang berupa nilai kebudayaan (Soekanto, 1990:479).

Desa Purwodadi merupakan desa yang berada di wilayah Kecamatan Barat Kabupaten Magetan. Kecamatan Barat merupakan wilayah pertanian yang menjadi salah satu penyokong kebutuhan pangan masyarakat di Kabupaten Magetan. Luas wilayah Desa Purwodadi Mencapai 122.255 $\mathrm{Ha}$, kurang dari $40 \%$ wilayahnya yaitu 
mencapai $55.610 \mathrm{Ha}$, merupakan daerah persawahan baik sawah dengan irigasi teknis, sawah irigasi setengah teknis dan sawah tadah hujan. Jumlah penduduknya mencapai 2.657 jiwa, 1.198 jiwa penduduk pria dan 1.457 jiwa perempuan. Masyarakat Desa Purwodadi, Kecamatan Barat, Kabupaten Magetan mempunyai mata pencaharian yang majemuk yang terdiri atas pedagang, petani, PNS, dan di bidang jasa. (Data Monografi Desa Purwodadi, Kecamatan Barat, Kabuten Magetan Tahun 2010). Desa Purwodadi juga memiliki tradisi budaya yang khas dan masih terjaga sampai dengan saat ini sehingga menarik untuk diteliti perkembangannya baik dari aspek sosial maupun budaya.

\section{Tujuan dan Manfaat Penelitian}

Tujuan penelitian ini sebagai berikut.

1. Mengungkap perkembangan sosial Desa Purwodadi tahun 1990-2010 dan dampak-dampak yang ditimbulkannya.

2. Mengungkap perkembangan budaya Desa Purwodadi tahun 1990-2010 dan dampak-dampak yang ditimbulkannya.

Penelitian ini diharapkan dapat bermanfaat sebagai berikut.

1. Bagi Masyarakat

a) Sebagai dokumentasi kesejarahan yang berkaitan dengan Sejarah dan perkembangan sosial budaya Desa Purwodadi Kecamatan Barat Kabupaten Magetan

b) Sebagai sarana pembangun wawasan kesejarahan, sosial dan budaya.

2. Bagi Program Studi Pendidikan Sejarah dan IKIP PGRI Madiun

a) Menambah koleksi Perpustakaan/ Laboratorium Pendidikan Sejarah dan Perpustakaan IKIP PGRI Madiun berupa karya ilmiah

b) Sebagai sumbangan bagi penelitian lebih lanjut.
3. Bagi Pemerintah Kabupaten Magetan

a) Sebagai arsip kesejarahan yang berkaitan dengan sosial budaya Desa Purwodadi Kecamatan Barat Kabupaten Magetan

b) Sebagai pembangun wawasan kesejarahan dan sumbangan bagi pembangunan wisata sejarah di Kabupaten Magetan.

\section{Tinjauan Pustaka}

\section{Desa}

Desa diistilahkan sebagai dusun, kampung, suatu tempat yang dihuni beberapa rumah yang berada di luar kota, pedalaman, udik, daerah, tanah, tempat (Team, 1997:166). Menurut Kartohadikoesoemo, (1984:16) desa adalah suatu kesatuan hukum, dimana bertempat tinggal suatu masyarakat mengadakan pemerintahan sendiri.

Pendapat senada dikemukakan oleh Bintarto, (1984:11) bahwa sebenarnya desa itu adalah suatu hasil perpaduan antara kegiatan sekelompok manusia dengan lingkungannya. Hasil dari perpaduan itu ialah suatu wujud atau kenampakan di muka bumi yang ditimbulkan oleh unsur-unsur fisiografi, sosial, ekonomi, politik dan kultural yang saling berinteraksi dalam hubungannya dengan daerah-daerah lain.

Berdasarkan pendapat di atas, maka desa dapat diberikan batasan pengertian dengan dasar pemikiran dan karakteristik yaitu aspek morfologi, aspek jumlah penduduk, aspek ekonomi dan aspek sosial budaya. Dilihat dari aspek morfologi, desa adalah pemanfaatan lahan atau tanah oleh penduduk atau masyarakat yang bersifat agraris, serta bangunan rumah tinggal yang terpancar atau jarang. Dilihat dari aspek jumlah penduduk, maka desa didiami oleh sejumlah kecil penduduk dengan kepadatan yang rendah. Dilihat dari aspek ekonomi, 
desa adalah wilayah yang penduduk atau masyarakatnya bermata pencaharian pokok di bidang pertanian, bercocok tanam atau agraris, dan nelayan. Sedangkan jika dilihat dari segi sosial budaya, desa itu tampak dari hubungan sosial antar penduduknya yang bersifat khas, yakni hubungan kekeluargaan, bersifat pribadi, tidak banyak pilihan dan kurang tampak adanya pengkotaan, bersifat homogen, serta bergotong royong. (Asy'ari, 1993:93-94).

Desa sebagai tempat tinggal sejumlah kecil manusia memiliki unsur-unsur yang membangun karekteristik dan sebagai identitas pembeda apabila dibandingkan dengan kota. Tipologi masyarakat desa berdasarkan kegiatan pokok yang ditekuni penduduknya guna memenuhi kebutuhan hidup sehari-hari, diantaranya desa pertanian dimana semua anggota masyarakatnya terlibat dibidang pertanian. Desa industri dimana pendapatan anggota masyarakatnya lebih banyak berhubungan dengan industri kecil atau kerajinan yang ada di desa tersebut. Desa nelayan atau desa pantai adalah pusat kegiatan dari seluruh anggota masyarakatnya bersumber pada usahausaha di bidang perikanan. (Nasikun, 1986:7).

Di samping tipologi desa tersebut, masih ada tipologi desa yag dilihat dari segi pemukiman seperti dikemukakan Landis dalam Nasikun, (1986:7-8) sebagai berikut.

a. Farm Village Type adalah desa di mana orang berdiam bersama dalam suatu tempat dengan sawah ladang di sekitar tempat itu. Tipe semacam ini banyak terdapat di Indonesia khususnya di Pulau Jawa. Demikian juga dengan dasar gotong-royong yang cukup kuat.

b. Nebulous Farm Village Type adalah suatu tipe dimana sejumlah orang berdiam bersama dalam suatu tempat, sebagian lainnya menyebar di luar tempat tersebut bersama sawah ladang mereka. Tipe semacam ini banyak terdapat di Indonesia khususnya di daerah Sulawesi Selatan, dan Pulau Jawa. Faktor tradisi gotong royong serta kolektivitas masih sangat kuat.

c. Arranged Isolated Farm Type adalah suatu desa di mana orang-orang berdiam di sekitar jalan-jalan yang berhubungan dengan trade center dan selebihnya sawah ladang mereka. Tipologi desa semacam ini banyak terdapat di negaranegara barat. Keadaan individualism sangat menonjol, tradisi kurang kuat, dan lebih berorientasi pada produksi di bidang perdagangan.

d. Pure Isolated Farm Type adalah suatu desa dimana orang berdiam tersebar bersama sawah ladang mereka masingmasing. Tipologi desa semacam ini banyak terdapat di negara-negara barat. Keadaan individualisme sangat menonjol, tradisi kurang kuat, dan lebih berorientasi pada produksi di bidang perdagangan.

\section{Perubahan Sosial Budaya}

Kata sosial secara etimologis berasal dari kata sofie dalam bahasa latin yang berarti bercocok tanam, kemudian berkembang menjadi socius yang artinya teman, kawan, berkembang, dan mengalami perubahan lagi menjadi kata sosial artinya berteman, bersama, berserikat. Secara khusus kata sosial maksutnya adalah hal-hal mengenai berbagai kejadian dalam masyarakat, sementara ilmu yang mempelajari masalah-masalah manusia dalam masyarakat dinamakan sosiologi (Shadily dalam Burhan, 2009:1-2)

Sementara pendapat Spencer dan Inkeles dalam Supardan (2008:69) mendefinisikan sosial melalui istilah sosiologi yang ditinjau dari harfiah berasal dari kata socius yang berarti kawan, berkawan, atau bermasyarakat dan logos berarti ilmu. Kata 
sosial dalam sosiologi yang dikemukakan Roucekj dan Waren adalah ilmu tentang hubungan antara manusia dalam kelompokkelompoknya atau masyarakat. Jadi yang diartikan sosial dari pendapat tersebut adalah kelompok-kelompok manusia atau masyarakat (Supardan, 2008:70).

Sebagai kesatuan-kesatuan khusus dari manusia yang saling berinteraksi, masyarakat tentunya memiliki unsur-unsur atau ciri-ciri, seperti yang dikemukakan Koentjaraningrat bahwa masyarakat sendiri merupakan sekumpulan manusia yang saling bergaul atau berinteraksi, suatu kelompok manusia mampu memiliki prasaran juga tidak lepas dari proses interaksi yang terjadi di dalamnya.

Suatu masyarakat dan sekumpulan orang yang melihat pertandingan sepak bola memiliki persamaan yaitu sekelompok manusia yang saling berinteraksi pada suatu tempat namun yang membedakan, masyarakat mempunyai suatu ikatan yang khusus yang dinamakan adat istiadat, sedangkan sekumpulan orang yang melihat pertandingan sepak bola hanya mempunyai ikatan yang terbatas yaitu sama-sama melihat pertandingan sepak bola. Selain adat istiadat, sekelompok orang yang berinteraksi dinamakan masyarakat haruslah memiliki pengatur tingkah laku dalam semua sektor kehidupan anggotanya yang dinamakan norma.

Suatu kesatuan manusia di dalam masyarakat haruslah memiliki pola tingkah laku yang khas terhadap semua faktor kehidupan dalam batas kesatuan, pola tersebut haruslah bersifat mantap dan berkelanjutan atau sudah menjadi adat istiadat yang khas. Suatu asrama pelajar, meskipun memiliki kesatuan manusia yang terdiri dari murid, guru, kepala sekolah, serta karyawan dan diatur tingkah-lakunya oleh norma atau aturan sekolah tetap saja tidak dapat dikatakan sebagai masyarakat karena sebagai kesatuan manusia, asrama tersebut hanya bersifat sementara dan tidak mempunyai keberlanjutan. Ciri yang terakhir adalah suatu rasa identitas diantara para warga atau anggotanya, bahwa mereka adalah satu kesatuan yang berbeda dari kesatuan-kesatuan manusia lainnya (Koentjaraningrat, 1990:143-146).

Semakin tinggi pola pikir manusia dalam kelompok masyarakat sosial akan memunculkan konsekuensi logis diantara mereka. Kebutuhan akan kepuasan jiwaraga, jasmani-rohani, material dan non material menjadi satu masalah seiring pendewasaan kelompok sosial tersebut, sampai pada akhirnya memunculkan lembaga-lembaga yang mampu mengakomodir kebutuhan-kebutuhan mereka atau pranata. Pranata adalah suatu sisten norma khusus yang menata suatu rangkaian tindakan, guna memenuhi suatu keperluan khusus dari manusia dalam kehidupan masyarakat. Semakin berkembangnya suatu masyarakat, akan mengakibatkan pula semakin bertambahnya jumlah pranata yang ada didalamnya.

Perkembangan masyarakat pada umumnya selalu diwarnai dengan lompatanlompatan status anggota di dalamnya. Kondisi sosial yang semacam itu dinamakan mobilitas sosial, yaitu suatu gerak dalam struktur sosial, yang memiliki pola-pola tertentu yang mengatur organisasi suatu kelompok manusia. Gerak sosial dimaksudkan sebagai perpindahan individu atau objek sosial dari suatu kedudukan sosial ke kedudukan yang lain dan tidak sederajat. Sesuai dengan arahnya terdapat dua gerak sosial seperti yang dijabarkan Soerjono Soekanto, (1990:275-277) adalah Social Climbing dan Social Sinking. Social Climbing atau gerak sosial vertikal naik, dalam hal ini terdapat beberapa bentuk utama yaitu: masuknya individu-individu yang mempunyai kedudukan rendah ke dalam kedudukan 
yang lebih tinggi. Pembentukan kelompok baru, yang kemudian ditempatkan pada derajat yang lebih tinggi dari kedudukan individu-individu pembentuk kelompok tersebut.

Social Sinking atau gerak sosial vertical turun, yang juga mempunyai dua bentuk utama yaitu : turunya kedudukan individu pada kedudukan yang lebih rendah derajatnya. Turunya derajat kelompok individu yang dapat berupa disentegrasi kelompok sebagai kesatuan.

Adapun kebudayaan, secara etimologis berasal dari bahasa Sansekerta yaitu buddhayah merupakan bentuk jamak kata buddhi yang berarti budi atau akal. Kebudayaan diartikan sebagai hal-hal yang bersangkutan dengan budi atau akal (Soerjono Soekanto, 1990:188). Dilihat dari aspek antropologi, kebudayaan adalah keseluruhan sistem gagasan, tindakan, dan hasil karya manusia dalam masyarakat yang diperoleh melalui proses belajar (Sumardi Ramon, 1985:177)

Menurut pendapat E.B. Tylor dalam Soerjono Soekanto, (1990:188) mengemukakan kebudayaan adalah kompleks pengetahuan, kepercayaan, kesenian, moral, hukum, adat-istiadat, kemampuankemampuan, serta kebiasaan-kebiasaan yang didapatkan oleh manusia sebagai anggota masyarakat.

Sementara itu menurut Selo Soemardjan dan Soelaeman Soemardi dalam Soerjono Soekanto, (1990:189) mengemukakan kebudayaan sebagai hasil karya, rasa, dan cipta manusia. Karya masyarakat menghasilkan teknologi dan kebudayaan kebendaan atau kebudayaan jasmaniah yang diperlukan manusia untuk menguasai alam sekitar sehingga dapat diabdikan untuk keperluan masyarakat. Rasa yang meliputi jiwa manusia untuk mewujudkan kaidah-kaidah dan nilai-nilai sosial untuk mengatur masalah kemasya- rakatan, misalnya : agama, ideologi, kebatinan, kesenian dan semua unsur yang merupakan hasil ekspresi jiawa manusia yang hidup sebagai anggota masyarakat. Cipta merupakan kemampuan mental, kemampuan berfikir orang-orang yang hidup dalam masyarakat, antara lain : filsafat dan ilmu pengetahuan.

Melville J. Herskovits dalam Soerjono Soekanto, (1990:192) mengemukakan 4 unsur pokok kebudayaan yaitu : alat-alat teknologi, sistem ekonomi, keluarga, kekuasaan politik. Sementara Bronislaw Malinowski juga mengemukakan unsurunsur kebudayaan adalah : sistem norma yang memungkinkan kerja sama antara anggota masyarakat di dalam upaya menguasai alam sekelilingnya, organisasi ekonomi, alat dan lembaga atau petugas pendidikan, organisasi kekuatan.

Seorang antropolog yang bernama $\mathrm{C}$. Kluckhohn di dalam karyanya yang berjudul Universal Catagories of Culture menyempurnakan unsur-unsur budaya di atas menjadi tujuh unsur kebudayaan yang disebut Cultural Universals. Pendapat Kluckhohn dasari pada unsur-unsur yang dapat dijumpai pada kebudayaan di belahan bumi manapun, unsur-unsur tersebut antara lain: peralatan dan perlengkapan hidup manusia, yaitu: pakaian, perumahan, alatalat rumah tangga, senjata, alat-alat produksi, dan sebagainya. Mata pencaharian hidup dan sistem ekonomi, yaitu pertanian, sistem produksi, sistem distribusi dan sebagainya. Sistim kemasyarakatan, yaitu : sistem kekerabatan, organisasi politik, sistem hukum, sistem perkawinan. Bahasa, baik lesan maupun tertulis. Kesenian dapat berupa seni rupa, seni lukis, seni gerak dan sebagainya. Selain itu terdapat juga unsur sistem pengetahuan dan religi atau sistem kepercayaan (Soerjono Soekanto, 1990:192193). 
Koentjaraningrat dalam Elly $\mathrm{M}$. Setiadi dan kawan-kawan (2007:28-30) menguraikan wujud kebudayaan ada 3 adalah : Wujud kebudayaan sebagai kompleks ide-ide, gagasan-gagasan, nilai-nilai, norma-norma, dan peraturan-peraturan. Wujud yang kedua, budaya sebagai suatu kompleks aktifitas serta tindakan berpola dari manusia dalam masyarakat. Serta wujud kebudayaan yang ketiga merupakan benda-benda hasil karya manusia.

Wujud kebudayaan sebagai kompleks ide-ide, gagasan-gagasan, nilai-nilai, norma-norma, dan peraturan sebagainya. Wujud ini bersifat abstrak, tak dapat diraba, atau difoto dan tempatnya berada di dalam alam piker manusia dalam masyarakat. Kebudayaan ideal ini disebut juga tata kelakuan yang berfungsi mengatur, mengendalikan, dan memberi arah kepada tindakan, kelakuan dan perbuatan manusia dalam masyarakat.

Wujud budaya sebagai suatu kompleks aktivitas serta tindakan berpola dari manusia dalam masyarakat. Sistem sosial ini terdapat aktivitas-aktivitas manusia yang berinteraksi, bergaul, dan berhubungan satu dengan yang lainya dalam masyarakat. Bentuk kebudayaan ini kongret sehingga dapat diobsevasi, difoto, dan didokumentasikan, misalnya : bahasa, perilaku, dan sebagainya.

Wujud kebudayaan sebagai bendabenda hasil karya manusia yaitu seluruh hasil fisik karya manusia dalam masyarakat. Sifat bentuk budaya ini sangat kongret sehingga dapat diraba dan dilihat, misalnya : candi, batik, rumah, dan sebagainya.

Wujud kebudayaan dapat tersalurkan melalui perilaku manusia, selain itu budaya telah ada terlebih dahulu daripada lahirnya suatu generasi tertentu dan tidak akan mati dengan habisnya generasi yang bersangkutan. Budaya diperlukan oleh manusia dan diwujudkan dalam tingkah lakunya sebagai perwujudan karya manusia melalui proses interaksi, serta budaya mencakup aturanaturan yang berisikan kewajiban-kewajiban, tindakan-tindakan yang dilarang, dan diizinkan (Soekanto, 1990:199-200).

Kebudayaan sebagai perwujudan nilai-nilai dalam masyarakat akan selalu mengalami perkembangan seiring kemajuan pola pikir penggunanya, budaya akan senantiasa mengalami penyempurnaan guna kepuasan pencipta dan penggunanya atau yang identik dinamakan gerak kebudayaan. Hal tersebut seperti yang dikemukakan oleh Soerjono Soekanto (1990:210) menyebutkan gerak kebudayaan sebenarnya adalah gerak manusia yang hidup di dalam masyarakat yang menjadi wadah kebudayaan tadi. Gerak manusia terjadi disebabkan adanya hubungan manusia satu dengan manusia yang lainya dalam masyarakat. proses yang memungkinkan adanya gerak kebudayaan dalam masyarakat dinamakan akulturasi. Proses akulturasi terjadi bila suatu kelompok manusia dengan suatu kebudayaan dihadapkan pada unsur-unsur kebudayaan asing. Lambat laun unsur-unsur kebudayaan asing tersebut dapat diterima dalam kebudayaan sendiri, tanpa menghilangkan kepribadian budayaan asli itu sendiri, namun secara umum terdapat unsur-unsur kebudayaan yang sulit untuk berakulturasi sebaliknya juga ada unsur-unsur yang mudah diterima oleh suatu masyarakat.

Unsur-unsur kebudayaan asing yang sulit diterima oleh suatu masyarakat misalnya : unsur-unsur yang menyangkut sistem kepercayaan, serta unsur-unsur yang dipelajari pada taraf pertama proses sosialisasi, contohnya masyarakat Indonesia menjadikan nasi sebagai makanan pokok akan susah ketika mengubah dengan makanan yang lain. Sedangkan unsur-unsur kebudayaan asing yang mudah diterima oleh suatu masyarakat antara lain: unsur 
kebendaan seperti alat-alat yang mudah dipakai dan dirasakan sangat bermanfaat bagi manusia yang menerimanya. Unsurunsur yang terbukti membawa manfaat besar. Unsur-unsur yang mudah disesuaikan dengan keadaan masyarakat.

Pada umumnya generasi muda dianggap sebagai individu-indivudu yang cepat menerima masuknya unsur-unsur kebudayaan asing, hai ini disebabkan belum mantapnya unsur-unsur atau norma-norma tradisional dalam jiwa mereka yang menyebabkan lebih mudah menerima unsurunsur baru dari luar yang kemungkinan dapat mengubah kehidupan mereka. Sebaliknya generasi tua, dianggap sebagai individu yang kolot dan sukar menerima budaya-budaya baru, hal ini disebabkan karena norma-norma tradisional sudah tertanam dan mendarah daging (Soerjono Soekanto, 1990:210-212).

Proses akulturasi yang berjalan baik dapat menghasilkan integritas antara unsurunsur kebudayaan asing dengan unsurunsur kebudayaan sendiri. Dengan demikian, unsur-unsur kebudayaan asing tidak lagi dirasakan sebagai hal yang berasal dari luar, tetapi dianggap sebagai kebudayaan sendiri (Soekanto, 1990:212).

Perubahan sosial budaya adalah sebuah gejala berubahnya struktur sosial dan pola budaya dalam suatu masyarakat. Perubahan sosial budaya merupakan gejala umum yang terjadi sepanjang masa dalam setiap masyarakat. Perubahan itu terjadi sesuai dengan hakikat dan sifat dasar manusia yang selalu ingin mengadakan perubahan. Hirschman mengatakan bahwa kebosanan manusia sebenarnya merupakan penyebab dari perubahan. Ada tiga faktor yang dapat memengaruhi perubahan sosial, yaitu tekanan kerja dalam masyarakat, keefektifan komunikasi, perubahan lingkungan alam (O'Neil, 2006: 7-10).
Perubahan sosial budaya juga dapat timbul akibat timbulnya perubahan lingkungan masyarakat, penemuan baru, dan kontak dengan kebudayaan lain. Sebagai contoh berakhirnya zaman es berujung pada ditemukannya sistem pertanian, dan kemudian memancing inovasi-inovasi baru lainnya dalam kebudayaan.

\section{Metode Penelitian}

Penelitian ini dilaksanakan di Desa Purwodadi, Kecamatan Barat, Kabupaten Magetan dimulai pada bulan Februari sampai dengan Mei 2011. Data bersumber dari informan dan arsip atau dokumen. Informan adalah orang yang memberi keterangan atau orang yang menjadi sumber data dalam penelitian (Abdi Tama, 2001:185). Dokumen dalam arti sempit kumpulan data verbal yang berbentuk tulisan. Dokumen dalam arti luas juga meliputi monumen, artefak, foto-foto, dan sebagainnya (Abdurahman, 2007:41).

Pengumpulan data dilakukan dengan teknik wawancara, observasi dan dokumentasi. Wawancara secara umum adalah proses memperoleh keterangan untuk tujuan penelitian dengan cara tanya jawab sambil bertatap muka antara pewawancara dengan informan atau orang yang diwawancarai (Burhan Bungin, 2007:108). Observasi adalah tindakan atau proses pengambilan informasi melalui media pengamatan (Sukardi, 2006:49). Dokumentasi ialah pengambilan data yang diperoleh melalui dokumen-dokumen (Husaini Usman, 2004:73). Sedangkan Burhan Bungin berpendapat metode dokumenter adalah metode yang digunakan untuk menelusuri data historis (Burhan Bungin, 2007:121)

Validasi data dilakukan melalui trianggulasi. Pada dasarnya trianggulasi. 
Pada dasarnya trianggulasi merupakan teknik yang didasari pada pola pikir fenomenologi yang bersifat multiperspektif, artinya untuk menarik sebuah kesimpulan yang mantap, diperlukan tidak hanya satu sudut pandang namun membutuhkan beberapa sudut pandang (Sutopo, 2006:92)

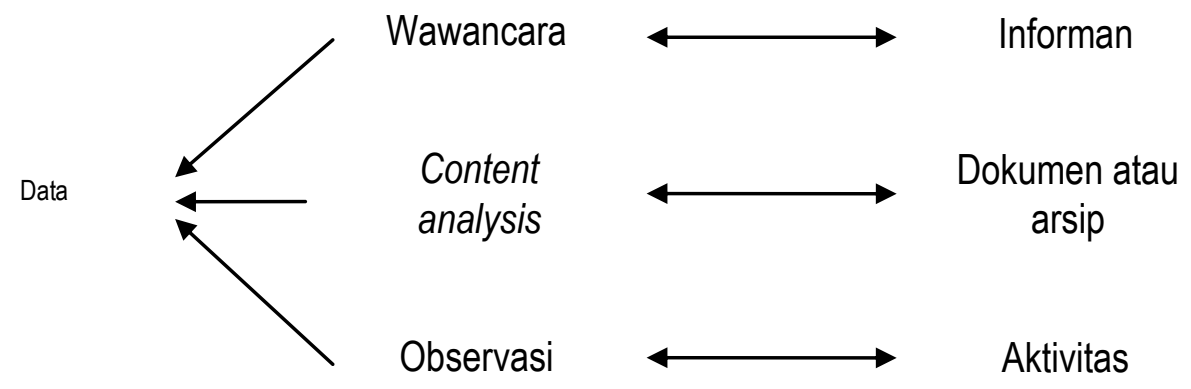

Bagan 1 : Bagan Trianggulasi Sumber

Analisis data penelitian ini lapangan dengan langsung menggunakan menggunakan model analisis interaktif. tiga komponen penelitian yaitu reduksi data, Model analisis interaktif memungkinkan penyajian data, dan penarikan kesimpulan untuk melakukan pengumpulan data di atau verifikasi (Sutopo, 2006:119).

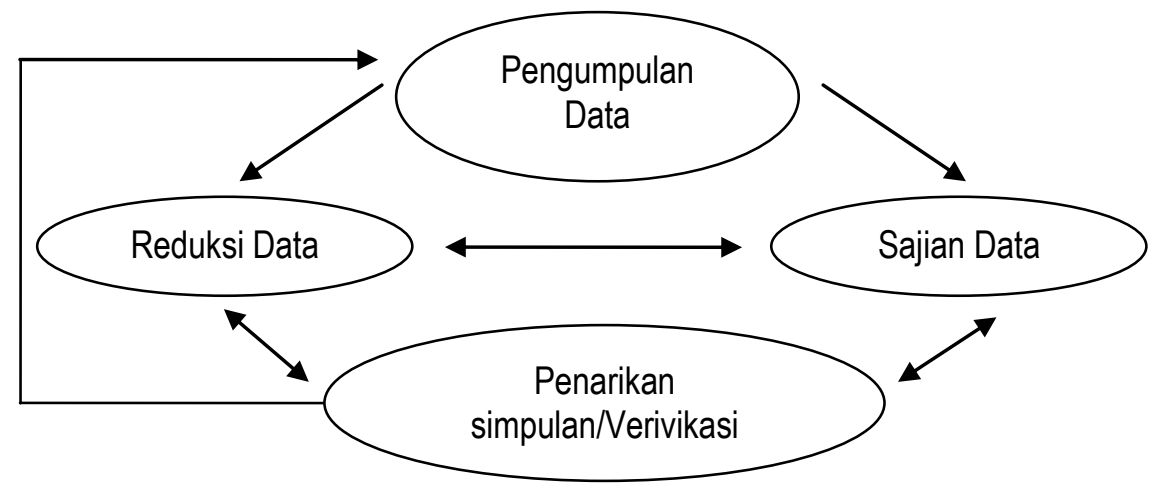

\section{Bagan 2 : Model Analisis Interaktif}

Hasil Penelitian

\section{Sejarah Awal Desa Purwodadi}

Sejarah Desa Purwodadi Kecamatan Barat Kabupaten Magetan tidak dapat dilepaskan dari keberadaan Kabupaten Magetan itu sendiri. Kabupaten Magetan merupakan sebuah wilayah di bawah kekuasaan Mataram Islam. Kabupaten Magetan masuk ke dalam wilayah Mancanegara Wetan yang terdiri dari Magetan, Madiun, Ngawi.

Sejarah Desa Purwodadi dimulai ketika Kabupaten Magetan diperintah oleh 
Bupati Tumenggung Sasrawinata yang memerintah Kabupaten Magetan tahun 1825 sampai dengan tahun 1837 (Wawancara dengan Soertarjono, 10 April 2011).

Pada masa pemerintahan Bupati Tumenggung Sasrawinata terdapat sebuah peristiwa penting, yaitu diadakannya konferensi oleh Pemerintah Belanda yang dihadiri semua Bupati Mancanegara Wetan. Konferensi dilaksanakan pada tanggal 4 Juli 1830 di Desa Sepreh Ngawi, dalam konferensi tersebut menetapkan semua Bupati Mancanegara Wetan harus menolak kekuasaan Sultan Yogyakarta dan Susuhunan Surakarta dan tunduk kepada pemerintahan Belanda di Batavia. Melalui Konferensi itu secara otomatis wilayah Kabupaten Magetan menjadi daerah jajahan Belanda (Team, t.t: 40)

Kabupaten Magetan di bawah jajahan Belanda membawa dampak yang besar diantaranya, wilayah Kabupaten Magetan dipecah menjadi tujuh daerah yaitu : Kabupaten Magetan I atau Magetan Kota, Bupatinya adalah R.T Sasrawinata, Kabupaten Magetan II di Plaosan, Bupatinya adalah R.T Purwawinata. Kabupaten Magetan III di Panekan, Bupatinya adalah R.T Sastradipura. Kabupaten Magetan IV di Goranggareng Genengan, Bupatinya adalah R.T Sasraprawira berasal dari Madura. Kabupaten Magetan V di Goranggareng Ngadireja, Bupatinya adalah R.T Sastradiryo. Kabupaten Maospati, Bupatinya adalah R. T Yudaprawira, dan Kabupaten Purwodadi Bupatinya adalah R. Ngabehi Mangunnagara (Team, t.t: 40). Pemecahan kekuasaan oleh belanda itu bertujuan sebagai pelemah kekuasaan Mataram, khususnya di wilayah Mancanara Wetan, selain itu sebagai usaha untuk mempermudah pengawasan dan pemerintahan setelah menjadi bawahan Pemerintah Belanda di Batavia (Wawancara dengan Soertarjono, 10 April 2011).
Kabupaten Purwodadi di bawah Bupatinya adalah R.Ngabehi Mangunnagara memiliki wilayah kekuasaan mencapai PG Purwodadie, di sebelah barat, sedangkan sebelah utara hamper mencapai wilayah Kabupaten Ngawi saat ini. Pusat pemerintahan Kabupaten Purwodadi berada di desa Purwodadi saat ini, dan reruntuhan Kadipaten Purwodadi masih dapat dilihat sampai dengan sekarang (Wawancara dengan Soertarjono, 10 April 2011).

Setelah Bupati R.Ngabehi

Mangunnagara meninggal, secara berturutturut Kabupaten Purwodadi diperintah oleh R.T Ranadirja, R.T Sumadilaga, R.T Surakusuma, dan R.M.T Sasranegara yang pemerintahannya berakhir pada akhir tahun 1860-an.

Berakhirnya pemerintahan R.M.T Sasranegara disebabkan penghapusan Kabupaten Purwodadi oleh Pemerintah Belanda. Wilayah Kabupaten Purwodadi dipecah-pecah menjadi beberapa desa, diantaranya desa Patihan, Kauman, Samberembe dan lain-lain. Sedangkan pada pusat pemerintahan Purwodadi sendiri dibagi menjadi Desa Purwodadi dan Desa Temulus. Desa Purwodadi kemudian diperintah oleh Martoikromo. Sepeninggalan Martoikromo, kemudian digantikan oleh Riwuk, dikarenakan alasan yang tidak jelas akhirnya Riwuk mengundurkan diri dan digantikan oleh Kromoredjo. Desa Temulus diperintah oleh Sastrogatook. Sepeninggalan Sastrogatook, kemudian digantikan oleh Martowidjoyo, dan setelah Martowidjoyo meninggal kemudian digantikan oleh Pontjoredjo.

Pada tahun 1922, Desa Purwodadi dan Desa Temulus dijadikan menjadi satu pemerintahan desa, yaitu menjadi Desa Purwodadi dengan luas wilayah sama dengan luas wilayah Desa Purwodadi saat ini. Lurah-lurah yang memerintah Desa Purwodadi secara berturut-turut adalah 
Toradjo menjabat tahu 1922 - 1953, kemudian digantikan Losodihardjo yang menjabat tahun 1953 - 1968, sepeninggalan Losodihardjo jabatan Kepala Desa dipegang oleh Kanmo yang memerintah tahun 1968 1970, kemudian digantikan Atmo Prawirokarno yang menjabat tahun 1970 1990, berakhirnya pemerintahan Atmo Prawirokarno kemudian digantikan Latiyanto menjabat tahun 1990-1998, dan Didik Diarto adalah Kepala Desa Purwodadi saat ini, yang memerintah sejak tahun 1998.

\section{Perubahan Sosial Desa Purwodadi Tahun 1990-2010}

a. Sebelum Tahun 1990-1995

Keberadaan kondisi Ggeografis Desa Purwodadi merupakan daerah agraris yang memiliki lebih dari 40\% wilayahnnya merupakan kawasan pertanian memungkinkan masyarakatnnya juga menggantungkan kehidupannya pada alam. Melalui pertanian masyarakat Purwodadi mampu memenuhi kebutuhan kehidupan mereka, dari kondisi geografis yang sebagian besar wilayahnnya persawahan masih ditambah lagi kesuburan tanah juga masih terjaga dengan baik sangat mampu mengangkat taraf hidup sebagian besar masyarakat Purwodadi.

Keberadaan adat istiadat yang berkembang di Desa Purwodadi, Kecamatan Barat, Kabupaten Magetan juga tidak dapat dipisahkan dari keberadaan masyarakat agraris sebagai mayoritas profesi yang digeluti. Salah satu budaya yang mencerminkan kehidupan agraris masyarakat Purwodadi adalah prosesi "medhel" yaitu slamatan sebelum panen dilaksanakan, serta masih adanya sesajen yang berisi nasi lengkap dengan lauk-pauk, bunga tujuh rupa dan beras kuning yang diletakkan pada seluruh sudut sawah atau kebun saat prosesi medhel dilaksanakan. Budaya "medhel" tersebut mengandung filosofi perwujudan syukur kepada Tuhan terhadap hasil panen yang didapat dan doa pengharapan untuk hasil yang melimpah pada panen yang akan datang, tidak ada yang tahu dengan jelas kapan budaya "medhel" tersebut pertama dilaksanakan oleh masyarakat Purwodadi, namun jika dilihat dari bentuk pelaksanaannya merupakan kebudayaan akulturasi Hindu dan Islam.

Keberadaan sistem norma sosial yang kurang dipahami oleh beberapa lapisan masyarakat Purwodadi banyak terjadi permasalahan tindak pidana yang terjadi di Desa Purwodadi serta melibatkan warga masyarakat Purwodadi, diantara permasalahan tersebut yang paling banyak adalah tindak kriminal yang disebabkan oleh kenakalan remaja diantarannya tawuran, pencurian, dll. Kondisi semacam itu kontras masyarakat Purwodadi yang sebagian besar hanya mengenyam pendidikan di bangku SLTA serta keberadaan lembaga masyarakat yang belum mampu berperan optimal sebagai pengawas, dan penengah dari setiap perselisihan antara warga. Kesadaran norma yang ada dalam masyarakat seharusnnya mampu dipahami warga Desa Purwodadi tidak hanya melalui bangku sekolah, dan ternyata sebagian besar masyarakat umumnya generasi tua sangatlah menjaga kerukunan, hanya saja generasi mudannya yang kurang menjaga kerukunan baik dengan sesama warga maupun warga dari luar Purwodadi.

Sebelum tahun 1990-an budaya gotong-royong menjadi aktifitas rutin yang dilaksanakan warga masyarakat Purwodadi, diantarannya pembersihan saluran irigasi ke sawah-sawah warga, pembersihan lingkungan desa secara berkala dan gotong royong antar warga yang memiliki hajat. Selain budaya gotong-royong yang menjadi ciri kekhasan Desa Purwodadi, sebelum tahun 1990-an masyarakat Purwodadi sangatlah menghargai keberadaan orang asing yang 
masuk di desanya. Kesadaran warga Desa Purwodadi terhadap nilai-nilai sosial khususnya budaya gotong-royong tidak dapat dipisahkan dari kondisi sosial masyarakat pada waktu itu yaitu sebagai petani. Masih terjagannya budaya gotongroyong menandakan masih terjagannya nilai-nilai toleransi diantara warga masyarakat Purwodadi.

\section{b. Tahun 1995 Sampai Dengan Tahun 2000}

Perkembangan pemahaman norma dan sistem norma pada masyarakat Purwodadi sedikit demi sedikit telah mampu dipahami oleh beberapa lapisan masyarakat, hal ini terbukti semakin berkurangnnya tindak kriminal yang terjadi di Desa Purwodadi yang melibatkan anggota masyarakatnnya. Hal tersebut seiring dengan kemajuan pola berfikir serta semakin meningkatnya pendidikan warga Desa Purwodadi.

Semakin kemajuan pola berfikir serta semakin meningkatnya pendidikan warga Desa Purwodadi juga membawa dampak pada kemunduran sistem sosial yang terjadi pada Desa Purwodadi nampak pada semakin berkurangnya masyarakat yang melaksanakan prosesi "Medhel" yang sebelumnnya menjadi tradisi yang tidak dapat ditinggalkan, sedikit demi sedikit mulai diabaikan pelaksanaanya oleh masyarakat Purwodadi walaupun mayoritas masih mengadakan saat datangnya panen raya.

\section{c. Tahun 2000 Sampai Dengan Tahun 2005}

Pada tahun 2002 mata pencaharian masyarakat Purwodadi tidak lagi mayoritas sebagai petani, masyarakat Purwodadi mulai mencari sumber penghasilan baru yang sebelumnnya menggantungkan kehidupannya pada sektor pertanian. Pergeseran mata pencaharian masyarakat Purwodadi tersebut merupakan dampak dari semakin menyempitnnya lahan pertanian di Purwodadi akibat dari bertambahnya pemukiman baru selain itu lahan pertanian tidak lagi mempunyai kesuburan yang optimal akibat dari penggunaan bahan-bahan kimia yang berlebihan pada tanah. Keberlanjutan lahan pertanian serta hasil yang maksimal merupakan tagung jawab masyarakat, bagaimana cara pengolahan demi keberlanjutan serta kesuburan tanah agar tetap terjaga merupan sesuatu yang berharga guna keberlanjutan kwalitas dan kwantitas sektor pertanian di Purwodadi.

Perubahan nilai-nilai sosial Desa Purwodadi selain nampak pada beragamnya mata pencaharian wagranya yang disebabkan sektor pertanian tidak lagi menjanjikan sebagai tumpuan ekonomi masyarakan, perubahan yang lai nampak pada pola interaksi Desa Purwodadi bisa dikatakan mengalami suatu kemunduran, hal tersebut dapat kita lihat dari kegiatankegiatan diantaranya gotong-royong yang dapat dilihat pada kegiatan kerja bhakti, membantu warga yang sedang melaksanakan hajatan hanya berorientasi terhadap materi. Keberagaman mata pencaharian yang masyarakat Purwodadi serta tuntutan sosial yang semakin meningkat telah merubah dan mengikis budaya gotong-royong antar warga Purwodadi. Sebagai masyarakat desa, seharusnya masyarakat Purwodadi tetap menjaga dan melestarikan nilai-nilai moral pada budaya gotong-royong, selain mengandung maksud kebersamaan dan kekeluargaan, gotong-royong merupakan identitas dari masyarakat pedesaan yang selalu mengatasi dan menyelesaikan masalah dengan cara kebersamaan.

\section{d. Tahun 2005 Sampai Dengan Tahun 2010 \\ Perkembangan pada keberadaan lembaga-lembaga masyarakat di Desa Purwodadi, antara lain Karangtaruna, Forum Kemitraan Polisi dengan Masyarakat atau}


FKPM, Badan Permusyawarahan Desa atau $B P D$, hal tersebut menunjukan semakin maksimalnya peran pemerintah dalam membina dan mengarahkan warga masyarakat Purwodadi kedalam wadahwada yang mampu menampung aspirasi dan ide sebagai tempat pelatihan berlembaga atau berorganisasi pada seluruh lapisan masyarakat. Meningkat atau semakin optimalnnya lembaga masyarakat tersebut tidak dapat dilepaskan dari semakin baiknya sumber daya manusia yang ada di Desa Purwodadi, dari kondisi yang ada tersebut diharapkan mampu menjadi awal dari modernisasi pola berfikir serta pembelajaran pada masyarakat untuk menyalurkan ide maupun aspirasi pada tempat yang benar.

Perubahan mata pencaharian yang terjadi pada masyarakat Purwodadi yang disebabkan semakin bertambahnya masyarakat serta semkin mengikis lahan-lahan pertanian menyebabkan keberagaman pada tingkat pendapatan masyarakat Purwodadi, selain itu dari perbedaan tingkat pendapatan masyarakat tersebut kemudian menyebabkan struktur masyarakat Purwodadi menjadi beragam atau bersifat heterogen dilihat dari strata sosial dan mata pencahariannya. Keberagaman mata pencaharian saat ini tidak akan terjadi selagi sektor pertanian selalu dapat menjadi tulang punggung masyarakat Purwodadi, namun yang terjadi kehidupan petani semakin lama semakin terpinggirkan yang dikarenakan hasil pertanian bisa dikatakan kurang memberikan kesejahteraan masyarakat Purwodadi saat ini. Para petani di Desa Purwodadi seharusnya memiliki pemikiran kedepan terhadap keberlanjutan lahan-lahan pertanian mereka serta menjaga kwalitas lahannya sehingga memberikan penghasilan yang berkesinambungan, melalui pengurangan penggunaan bahan-bahan kimia dan kembali pada pupuk organik merupakan salah satu solusi sebagai tindakan mengembalikan kesuburan tanah tanpa bahan-bahan kimia sehingga baik kwalitas maupun kwantitas sektor pertanian dapat terjaga.

Sebagai dampak dari pergeseran pada mata pencaharian masyarakat Purwodadi yang kemudian membawa akibat semakin beragamnya status-satatus sosial pada masyarakat Purwodadi yang terlihat pada pola pergaulan serta gaya hidup masyarakat Purwodadi. Perkembangan pola pergaulan dan gaya hidup yang terjadi di Desa Purwodadi juga dapat dilihat dari keberadaan tempat tinggal atau rumah penduduk yang telah mencerminkan adanya peningkatan serta pencerminan dari keberagaman tingkat kesejahteraan masyarakatnya.

Menurut beberapa informan, bentukbentuk rumah pada masa dahulu mayoritas mencerminkan sebagai tempat tinggal seorang petani lengkap dengan kandang, halaman yang luas, namun saat ini keberadaan rumah-rumah di Desa Purwodadi telah mampu menunjukan struktur kelas sosial masyarakatnya yang beragam. Selain itu perkembangan pola pergaulan dan gaya hidup masyarakat Purwodadi dapat dilihat dari gaya berpakaian masyarakatnya yang bisa dikatakan mendekati gaya berpakaian orang-orang perkotaan dan lambat laun telah meninggalkan cerminan orang-orang desa.

Dampak modernisasi serta mulai bergesernya kehidupan-kehidupan pedesaan ditandai semakin lunturnya nilai gotongroyang, pergeseran mata pencaharian masyarakat di bidang pertanian memunculkan kehidupan masyarakat pedesaan yang masyarakatnya telah mempunyai jiwa masyarakat perkotaan. Sebagai ujung dari perubahan struktur sosial adalah memungkinkannya Desa Purwodadi bergeser dari 
desa agraris menjadi desa industri, atau desa perdagangan, dan bahkan mampu menjadi desa setengah kota.

\section{Perubahan Budaya Desa Purwodadi Tahun 1990-2010}

a. Sebelum Tahun 1990 Sampai Dengan Tahun 1995

Struktur masyarakat Purwodadi yang beragam serta masih kentalnya hormat menghormati antar warga menyebabkan bahasa yang digunakan Masyarakat Desa Purwodadi adalah bahasa jawa, didalam bahasa jawa itu sendiri mempunyai struktur bahasa yang bermacam-macam sesuai dengan lawan bicara yang kita hadapi, mereka-mereka yang menggunakan bahasa jawa dengan baik kebanyakan merekamereka yang memiliki usia lanjut serta tingkat pendidikan yang rendah, namun dalam setiap kesempatan yang sifatnya resmi misalnya pertemuan atau rapat di kantor desa atau pertemuan antara tokohtokoh masyarakat selalu menggunakan Bahasa Indonesia

Desa Purwodadi, Kecamatan Barat, Kabupaten Magetan sebelum tahun 1990-an pernah muncul kesenian-kesenian yang bernafaskan agama Islam diantaranya kesenian Gembrung, Jedor, dan Terbang. Kesenian Gembrung, Jedor, serta Terbang. Kesenian-kesenian tersebut pernah mengalami masa keemasannya sekitaran tahun 1970-an sampai dengan akhir tahun 1990-an. Masa keemasan keseniankesenian tersebut tidak dapat dilepaskan dari belum maraknya kesenian-kesenian yang lebih modern seperti masa sekarang.

Sejarah Desa Purwodadi, Kecamatan Barat, Kabupaten Magetan yang merupakan bekas Ibukota Kadipaten Purwodadi pada masa lalu merupakan sebuah posisi yang penting dan strategis. Posisi sebagai pusat Kadipaten memungkinkan tumbuh berkembangannya kebudayaan-kebudayaan yang bernilai tinggi jika dibandingkan dengan daerah yang memiliki kedudukan biasa. Menurut beberapa narasumber awalnya masyarakat Desa Purwodadi memiliki tingkat religiusitas yang tinggi, hal ini saangat dimungkinkan jika dilihat dari sejarah Kadipaten Purwodadi itu sendiri yang awalnya merupakan wilayah dari Kesultanan Mataram Islam. Kultur masyarakat Purwodadi yang sebagian besar merupakan pemeluk agama Islam membawa dampak tumbuh dan berkembangnya kebudayaankebudayaan yang bernafaskan agama Islam. Kebudayaan atau kesenian yang pernah berkembang di Desa Purwodadi, Kecamatan Barat, Kabupaten Magetan, diantaranya kesenian Terbang, Gembrung, dan Jedor

Masyarakat Purwodadi pada tahun 1990 sebagian besar masih menggantungkan kehidupannya pada sektor pertanian, para petani di Desa Purwodadi menduduki profesi paling banyak digeluti masyarakat Purwodadi yang terdiri dari petani yang memiliki sawah maupun yang hanya sebagai buruh tani saja. Sedangkan dalam proses penggarapan lahan untuk pertanian di Desa Purwodadi sampai pada saat pemanenan masih menggunakan cara-cara manual dan sangat mengandalkan kemurahan dari alam, pembajakan masih mengunakan hewanhewan ternak, dan satu tahun hanya mampu melaksanakan panen 2 kali.

\section{b. Tahun 1995 Sampai Dengan Tahun 2000 \\ Pengolahan lahan pertanian,} masyarakat Desa Purwodadi telah menggunakan teknologi semi modern. Walaupun perubahan itu tidak serta merta dapat dikerjakan oleh seluruh masyarakat Purwodadi, namun secara lambat laun perkembangan pola pengolahan lahan pertanian mulai dilakukan hampir semua petani di Purwodadi, selain itu perkembangan teknologi Desa Purwodadi dapat 
dilihat melalui keberadaan akses baik telekomunikasi dan transportasi bisa dikatakan telah modern dengan telah adanya telfon, internet melalui warungwarung internet yang berada di Desa Purwodadi, jalan-jalan desa atau akses jalan kecamatan telah beraspal, serta keberadaan kendaraan umum baik antar kecamatan maupun kabupaten. Perubahan yang terjadi pada sektor toknologi tidak dapat dilepaskan dari semakin meningkatnnya kwalitas sumber daya manusia Desa Purwodadi yang secara lambat laun mengalami peningkatan dan perbaikan yang diakibatkan semakin meningkatnnya status sosial masyarakat Purwodadi itu sendiri.

\section{c. Tahun 2000 Sampai Dengan Tahun 2005}

Perkembangan budaya di Desa Purwodadi khususnya pada unsur mata pencaharian dapat dilihat melalui adanya sistem sewa tanah. Sistem sewa bagi yang dilakukan masyarakat Desa Purwodadi dikenal masyarakat sekitar tahun 1980-an, kondisi tersebut tidak serta merta dilakukan oleh seluruh masyarakat Desa Purwodadi yang memiliki lahan pertanian, namun lambat laun kepemilikan lahan pertanian mulai banyak yang disewakan dengan sistem bagi hasil dengan buruh-buruh tani yang menggarap lahannya tersebut maupun kepada PG Purwodadie, hal tersebut didasari pada semakin sempitnya lahan pertanian serta sektor pertanian tidak lagi memberikan hasil yang maksimal untuk memenuhi kebutuhan hidup yang semakin mahal. Sewa tanah sendiri sebagai perwujudan masyarakat Purwodadi yang memiliki profesi ganda selain sebagai petani yang lahannya disewakan, mereka juga memiliki pekerjaan yang lain diantaranya pedagang, buruh industri, dan pegawai negeri sipil atau PNS.

Keberadaan para petani yang mulai terpinggirkan kemudian menyewakan lahan- nya membawa dampak juga pada perubahan pada sektor mata pencaharian penduduknya saat ini, diantaranya pedagang, industri, pegawai negeri sipil atau PNS, industri yang sebelumnya hanya bermata pencaharian di sektor agraris.

\section{d. Tahun 2005 Sampai Dengan Tahun 2010}

Perkembangan sistem pengetahuan masyarakat Desa Purwodadi, Kecamatan Barat, Kabupaten Magetan tidak dapat dilepaskan dari tingkat serata kesadaran terhadap pendidikan, hal ini dapat dilihat dari lulusan dari perguruan tinggi yang terus mengalami peningkatan dari tahun ke tahun, misalnya pada tahun 2010 masyarakat Purwodadi yang memiliki latar belakang pendidikan S-1 sebanyak 33 orang, dan S-2 mencapai 5 orang. Selain disebabkan oleh tingkat kesadaran masyarakatnya perkembangan sistem pengetahuan masyarakat Desa Purwodadi, juga disebabkan oleh semakin beragamnya struktur sosial Desa Purwodadi dan pada akhirnya juga membawa keberagaman status sosial masyarakatnya juga.

Kemajuan pola organisasi sosial atau organisasi kemasyarakatan di Desa Purwodadi, serta banyaknya lembagalembaga yang mampu mewadahi seluruh golongan masyarakat Purwodadi diantaranya: Karangtaruna, Forum Kemitraan Polisi dengan Masyarakat atau FKPM, Badan Permusyawarahan Desa atau BPD yang bersinergi dengan pemerintahan desa, dan adanya kelompok-kelompok arisan dan yasinan sebagai tempat berkumpulnya warga masyarakat serta sebagai sarana penerus kebijakan desa terhadap masyarakat luas, adalah salah satu bukti semakin membaiknya sumber daya manusia Desa Purwodadi.

Kesenian Gembrung, Jedor, dan Terbang yang saat ini benar-benar telah 
mengalami kepunahan, merupakan salah satu bentuk kemunduran nilai-nilai budaya asli di Desa Purwodadi. kesenian Gembrung, Jedor, dan Terbang saat ini hanya sebagai hiburan para pemainnya yang sudah lanjut usia, dengan kata lain kesenian Gembrung, Jedor, dan Terbang hanya diminati segelintir masyaraat Purwodadi. Semakin modernya pola pikir masyarakat Purwodadi yang didasari semakin majunnya tingkat pendidikan merupakan salah satu faktor saat ini banyak kesenian-kesenian yang berasal dari Desa Purwodadi yang mengalami kemunduran bahkan telah hilang, sedangakan pendidikan atau sistem pengetahuan juga termasuk unsur dari kebudayaan seperti yang dikemukanan oleh E.B. Tylor dalam Soerjono Soekanto, (1990:188). Hal tersebut sesuai dengan kondisi yang ada di Desa Purwodadi

Modernisasi yang terjadi pada masyarakat Purwodadi yang ditandai semakin tingginnya tingkat pendidikan masyarakat merupakan penyebab semakin terkikisnya kesenian asli masyarakat Purwodadi, yaitu kesenian Gembrung, Jedor, dan Terbang. Peranan generasi muda yang seharusnya sebagai penerus kesenian-kesenian tersebut malah enggan bersentuhan bahkan ikut melestarikannya, hal tersebut nampak pada pemain kesenian Gembrung, Jedor, maupun Terbang yang sudah berusia lanjut. Generasi muda merupakan kelompok yang seharusnya berperan dalam proses pelestarian budaya, melalui generasi muda keberlanjutan kesenian-kesenian tersebut akan mampu terjaga, namun selama para generasi muda di Desa Purwodadi tidak mapu mengambil peran sebagai penerus kebudayaan tersebut lama kelamaan akan terkubur oleh budaya modernisasi yang saat ini telah menyerang sebagian besar unsur sosial masyarakat Desa Purwodadi.
Kemajuan kesenian-kesenian modern serta berkembangnya pola pikir masyarakat hal yang paling berperan dalam keberlanjutan kesenian Terbang, Gembrung, dan Jedor di Desa Purwodadi adalah peran masyarakat dan lembaga pemerintahan desa. Masyarakat Purwodadi khususnya generasi mudanya yang memandang keberadaan kesenian masyarakat seperti Terbang, Gembrung, dan Jedor hanya sebagai hiburan dan kurang mamahami nilai serta makna dibalik kesenian-kesenian tersebut. Peranan dari pemerintah desa juga sangatlah kurang dalam hal pelestarian serta penjagaan kesenian tersebut sebagai aset kebudayaan yang dimiliki Desa Purwodadi. Pemerintah seharusnnya juga memperhatikan kesenian Terbang, Gembrung, dan Jedor melalui bebrapa cara diantarannya menjadikan kesenian tersebut sebagai agenda rutin tahunan di Desa Purwodadi, seperti pelestarian pada budaya Bersih Desa yang rutin setiap tahun dilaksanakan.

Prosesi Bersih Desa merupakan agenga setiap tahun dan wajib diselenggarakan oleh Pemerintah Desa Purwodadi. Prosesi bersih desa dilakukan di punden Dusun Sudimoro dan Temulus. Prosesi atau ritual Bersih Desa itu sendiri merupakan prosesi slamatan yang diadakan di punden desa dan kemudian dilanjutkan dengan Kesenian Tayub yang diadakan di tempat yang sama, selain itu pada saat malam harinya dilanjutkan dengan Kesenian Ketoprak, namun pada saat ini hanya sebatas selamatan dan Kesenian Tayub saja yang masih dilaksanakan. Prosesi bersih desa masih sangat dipercaya oleh masyarakat Purwodadi merupakan sarana untuk membersihkan desanya serta sebagai pengharapan untuk kemakmuran dan kesejahteraan masyarakat Purwodadi kedepanya. 
Terjaganya prosesi Bersih Desa di Purwodadi tidak lepas dari peranan masyarakat serta pemerintah desa itu sendiri. Pemerintah desa yang menetapkan sebagai kesenian atau prosesi tahunan merupakan salah satu cara guna menjaga kelestarian kesenian tersebut, selain itu yang paling penting peranan masyarakat yang masih meyakini nilai dibalik Prosesi Bersih Desa tersebut merupakan kekuatan terbesar yang menjaga kesenian tersebut masih ada sampai dengan sekarang ini.

\section{Simpulan dan Saran}

\section{Simpulan}

a. Sebelum tahun 1990-an, hampir seluruh masyarakat Desa Purwodadi menggantungkan kehidupannya pada sektor pertanian. Perubahan sosial diawali dengan semakin menyempitnya lahan pertanian serta sektor pertanian tidak lagi menjanjikan kemapanan status sosial. Yang dilakukan masyarakat Purwodadi adalah menyewakan lahan kepada penyewa perorangan maupun PG Purwodadie. Struktur sosial perlahan mulai berubah. Nilai-nilai sosial gotongroyong mulai luntur. Satu-satunya yang masih tersisa adalah tradisi Bersih Desa.

b. Desa Purwodadi sebagai bekas pusat Pemerintahan Kadipaten Purwodadi yang berlatar belakang agama Islam membawa dampak pada tumbuh dan berkembangnya kesenian-kesenian yang bernafaskan Islam, antara lain terbang, gembrung, dan jedor. Kesenian-kesenian tersebut pernah ada di Desa Purwodadi sebelum tahun 1990-an, saat ini mulai tergeser oleh bentuk-bentuk kesenian modern yang lebih mementingkan aspek hiburan.

\section{Saran}

a. Kepada Masyarakat Desa Purwodadi Hendaknya menjaga dan melestarikan peninggalan budaya baik dalam bentuk fisik maupun non fisik yang masih ada sampai dengan saat ini.

b. Kepada Pemerinta Desa Purwodadi

Diharapkan untuk lebih berperan aktif dalam penjagaan nilai-nilai sosial budaya yang ada di Desa Purwodadi serta memperhatikan budaya-budaya yang saat ini mulai ditinggalkan serta menghidupkan kembali menjadi aset Desa Purwodadi, selain itu mampu memberikan pelayanan yang lebih optimal kepada masyarakat.

c. Kepada Dinas Kebudayaan Kabupaten Magetan

Juga ikut berperan dalam pelestarian tinggalan kebudayaan yang ada di Desa Purwodadi melalui penerbitan aturan yang jelas perihal benda-benda cagar budaya yang ada di Desa Purwodadi, selain itu lebih berperan aktif untuk melestarikan budaya baik yang berwujud material dan non material. 
83|Agastya Vol. 02 No. 01 Januari 2012

\section{Daftar Pustaka}

Basrowi \& Suwandi. 2008. Memahami Penelitian Kualitatif. Jakarta: Rineka Cipta.

Burhan Bungin. 2007. Penelitian Kualitatif, Komunikatif, Ekonomi, Kebijakan Publik, dan IImu Sosial. Jakarta: Kencana Pranada Media Group.

Burhan Bungin. 2009. Sosiologi Komunikasi. Jakarta: Kencana Pranada Media Group.

Dadang Supardan. 2008. Pengantar IImu Sosiologi. Jakarta: Bumi Aksara.

Dadaung Abdurahman. 2007. Metodologi Penelitian Sejarah. Jogjakarta: ArRuzz Media Group.

Elly M. Setiadi dkk. 2007. Ilmu Sosial dan Budaya Dasar. Jakarta: Kencana Pranada Media Group.

Husaini Usman. 2004. Motodologi Penelitian Sosial. Jakarta: PT Bumi Aksara.

J. Nasikun. 1986. Sosiologi Pedesaan. Disunting oleh Jefta Leibo. 1986. Yogyakarta: Andi Offset.

Koentjaraningrat.1990. Pengantar IImu Antropologi.. Jakarta: Gramedia.

Lexy J. Moleong. 2007. Metodologi Penelitian Kualitatif. Bandung: PT Remaja Rosdakarya.

N. Daldjoeni. 1982. Geografi Kesejarahan I (Peradaban Dunia). Bandung: Penerbit Alumni.
N. Daldjoeni. 1987. Geografi Kota dan Desa. Bandung: Penerbit Alumni.

O'Neil, D. 2006. Cultural Anthropology Tutorials, Behavioral Sciences Department, Palomar College, San Marco, California.

Pemerinta Desa Purwodadi. 2003. Daftar Isian Potensi Desa dan Tingkat Perkembangan Desa. Magetan: Pemerintah Kabupaten Magetan Kantor Pemberdayaan Masyarakat Kabupaten Magetan.

Pemerintah Desa Purwodadi. 2006. Daftar Isian Potensi Desa dan Tingkat Perkembangan Desa. Magetan: Pemerintah Kabupaten Magetan Kantor Pemberdayaan Masyarakat Kabupaten Magetan.

Pemerintan Desa Purwodadi. 2009. Daftar Isian Potensi Desa dan Tingkat Perkembangan Desa. Magetan: Pemerintah Kabupaten Magetan Kantor Pemberdayaan Masyarakat Kabupaten Magetan.

R. Bintarto. 1984. Interaksi Desa-Kota dan Permasalahanya. Jakarta Timur: Ghalia Indonesia.

Soerjono Soekanto. 1990. Sosiologi suatu pengantar. Jakarta Utara : PT. Raja Grafindo Persada.

Soetardjo Kartohadikoesoemo. 1984. Desa. Jakarta: Balai Pustaka.

Sukardi. 2006. Penelitian KualitatifNaturalistik; dalam Pendidikan. Jakarta: Penerbit Usaha Keluarga. 
Sumardi Ramon. 1985. Pelajaran Sosiologi dan Antropologi. Surabaya: Sinar Wijaya.

Supari Imam Asy'ari. 1993. Sosiologi Kota dan Desa. Surabaya: Usaha Nasional.

Sutopo, H B. 2006. Metodologi Penelitian Kwalitatif Dasar Teori dan Terapannya dalam penelitian. Surakarta: Universita Sebelas Maret.

Anonim. tt. Apa dan Siapa Magetan?. Magetan: Pemerintah Kabupaten Daerah Tingkat II Magetan.

Team. tt. Sejarah Kabupaten Magetan. Magetan: Pemerintah Kabupaten Daerah Tingkat II Magetan. 